\title{
Grouse and ptarmigan nutrition in the wild and in captivity
}

\author{
BY ROBERT MOSS
}

\author{
Institute of Terrestrial Ecology, Banchory, Kincardineshire AB3I $4 B Y$
}

Birds of the grouse family (Tetraonidae) have a circumpolar distribution north of about $26^{\circ}$ latitude and are particularly adapted to browsing on coarse forage. The three species of ptarmigan (Lagopus lagopus, Lagopus mutus, Lagopus leucurus), for example, feed on dwarf shrubs such as blaeberry (Vaccinium myrtillus), heather (Calluna vulgaris) and crowberry (Empetrum spp.) and shrubs such as willow (Salix spp.) and birch (Betula spp.). Such foods are low in protein and $\mathrm{P}$ and contain much indigestible material such as lignin, tannins and resins (Moss \& Hanssen, 1980).

In winter, when their diet is at its most fibrous and indigestible, the birds need only to maintain themselves and have fewer nutritional problems than at other seasons. The two most critical periods for nutrition are egg-laying by hens and the chicks' first 2-3 weeks. Hens generally form and lay their eggs just as plants are beginning to grow and chicks hatch when both newly-growing vegetation and insect food are most available.

Ptarmigan (Lagopus; etymology: the hairy-footed) is the name given to tetraonid birds which turn white in winter. Two species of ptarmigan are circumpolar; the willow ptarmigan (Lagopus lagopus, also known as willow grouse) is the largest and lives at a lower altitude than the rock ptarmigan (Lagopus mutus, also called ptarmigan). The whitetailed ptarmigan (Lagopus leucurus), confined to North America, is the smallest of the three and lives at the highest altitudes. Confusingly, the red grouse (Lagopus lagopus scoticus) is a ptarmigan which does not turn white in winter.

\section{WINTER FOODS}

Polyphenols are the most widespread plant defence against herbivory. Pure cellulose is readily digested by grouse (Gasaway, 1976) but lignin binds to structural cellulose and makes it less digestible (Chesson, 1983), so that the nutrient-rich cell contents also become less available for digestion. A herbivore needs to eat a large bulk of such fibrous foods, which is associated with a short residence time in the gut and further reduces digestibility. An adaptation to this problem is increased gastrointestinal size, which increases the amount of food that can be held in the gastrointestinal tract for a given time, or increases the time available for digesting a given amount of food (Van Soest, 1982; Moss, 1983).

Another adaptation for digesting bulky food is to keep the gastrointestinal tract full of it. Tetraonids sleep at night, but store large volumes of food in the crop just before roosting and continue to process fresh food while asleep.

Tetraonid gastrointestinal anatomy seems to optimize the flow of digesta. As digesta leaves the small intestine, the chyme is separated into two fractions: a coarse, fibrous one which is rapidly voided through the short, muscular colo-rectum; and a more liquid fraction which enters the blind, tubular caeca. The main emptying of the two caeca occurs once daily, shortly after the bird wakes up in the morning, which indicates that digesta have a long residence time in the caeca.

When having large gastrointestinal tracts is no longer necessary for the digestion of low-quality winter diets, they soon become smaller. Thus, the gastrointestinal tract tends to be shorter in summer than in winter. The most spectacular example of reduced 
gastrointestinal size is when grouse are reared in captivity on foods which are easier to digest and richer in nutrients than natural winter foods. One can infer from this that large gastrointestinal tracts are expensive to maintain. There are physiological costs to large gastrointestinal tracts and, since grouse have to fly, one of the most obvious penalties is poorer flight and all that this entails. There is evidence that the most dominant sex and age classes have the shorter gastrointestinal tracts, from which one infers that birds use their dominance to ensure access to better foods (Moss, 1983).

The digestibility of a food is as much a property of the bird eating it as of the food itself. A typical winter food might be $40 \%$ digestible in wild birds, but much less in captives (Moss \& Hanssen, 1980). One needs to distinguish between the intrinsic digestibility of the food, determined by its physical and chemical nature, and the digestive abilities of the bird. An easily measured covariate of digestive abilities is gastrointestinal length (Moss, 1983), but there may be many other physiological aspects of adaptation to natural diets.

Smaller phenolic molecules, some perhaps derived from the digestion of tannins and lignins, are toxic when absorbed and must be detoxified. This needs the amino acid ornithine which is conjugated with benzoic acid, presumably an endproduct of phenolic catabolism, to produce ornithuric acid (Moss \& Parkinson, 1975). This requirement for an amino acid is likely to be especially problematical on typical low-protein winter foods. For example, about $17 \%$ of the total $\mathrm{N}$ excreted by captive red grouse on a diet of heather was as ornithuric acid (Moss \& Parkinson, 1972). Reverse peristalsis, wherein urinary $N$ is moved backwards up the colo-rectum and into the caeca, seems to be a means of recycling N (Mortensen \& Tindall, 1981).

According to many text books, birds excrete uric acid as the main endproduct of protein metabolism. The same is true for grouse catabolizing their own tissue. Otherwise, ammonium salts and sometimes urea are as plentiful in the droppings as is uric acid (Moss \& Hanssen, 1980). On low-protein diets, less urea is excreted. This pattern presumably reflects the need for $\mathrm{N}$ conservation on low-protein diets, but the mechanisms for this are not clear.

\section{SPRING FOODS FOR ADULTS}

In spring, the staple browse plants begin to grow and the diet of grouse and ptarmigan is further enriched by a wide range of newly-growing herbs and other digestible, nutrient-rich plant foods such as shoots of cotton grass Eriophorum spp. The hens now begin to lay their eggs.

\section{Captives}

The onset of new plant growth does not mean that the digestive problems of the birds are over. Most previous studies had looked at the digestion of winter foods. Welch et al. (1994) decided to measure the digestibility of freshly-cut, newly-growing heather and blaeberry to captive red grouse. Apparent digestibility $(0.80$ and 0.74 for newly-growing heather and blaeberry respectively) and DM intake $(>150 \mathrm{~g} / \mathrm{d}$ and about $100 \mathrm{~g} / \mathrm{d}$ for newly-growing heather and blaeberry respectively) were both much higher than in winter (typically 0.25 and $70 \mathrm{~g} / \mathrm{d}$ respectively for heather), but the birds rapidly lost weight.

Welch et al. (1994) tried to circumvent the problem of weight loss by measuring partial digestibilities of diets composed partly of natural foods and partly of standard maintenance pellets (digestibility 0.52 ). This was achieved by giving the birds limited 
amounts of pellets, with fresh food ad libitum, or vice versa. It was expected that the digestibility of such mixed diets would increase with increased proportions of natural foods, for when eaten alone the natural foods had been more digestible than pellets. In fact, the opposite happened (Fig. 1). With small proportions of natural foods, digestibilities of mixed diets were greater than for pure pellets, as expected. But, unexpectedly, as the proportions of natural foods increased, digestibilities of the mixed diets dropped. With decreasing digestibility, food intake increased (Fig. 2), indicating that limitation of intake was not due to the bulk of the diet.

Welch et al. (1994) also noted that both digestibility and intake were lower for blaeberry diets than for diets with the same proportion of heather. They concluded that new growth inhibited digestion in diets consisting mostly of new growth, and that blaeberry contained more (or a more potent version) of the digestion inhibitor than heather. This finding is similar to that for fescue (Festuca spp.) digestion in ruminants, wherein digestion-inhibiting alkaloids present in fescue decline in concentration with the age of the plant (Van Soest, 1982).

Although the captive stock was routinely fed with freshly-cut heather, which formed about $10 \%$ of their DM intake, there were no problems attributable to the presence of new growth in the diet. Indeed, this has been shown to stimulate egg-laying (Moss et al. 1971).

Presumably, just as wild birds can digest fibre better than captives (Moss, 1989), wild birds can cope with spring toxins better than captives. Much is unexplained. Nonetheless, we can conclude that in captive conditions a completely natural diet is not always the best one.

\section{Wild birds}

Despite the previously-mentioned findings with captives, the importance of newly-growing plant material in the spring nutrition of wild grouse and ptarmigan is well documented.

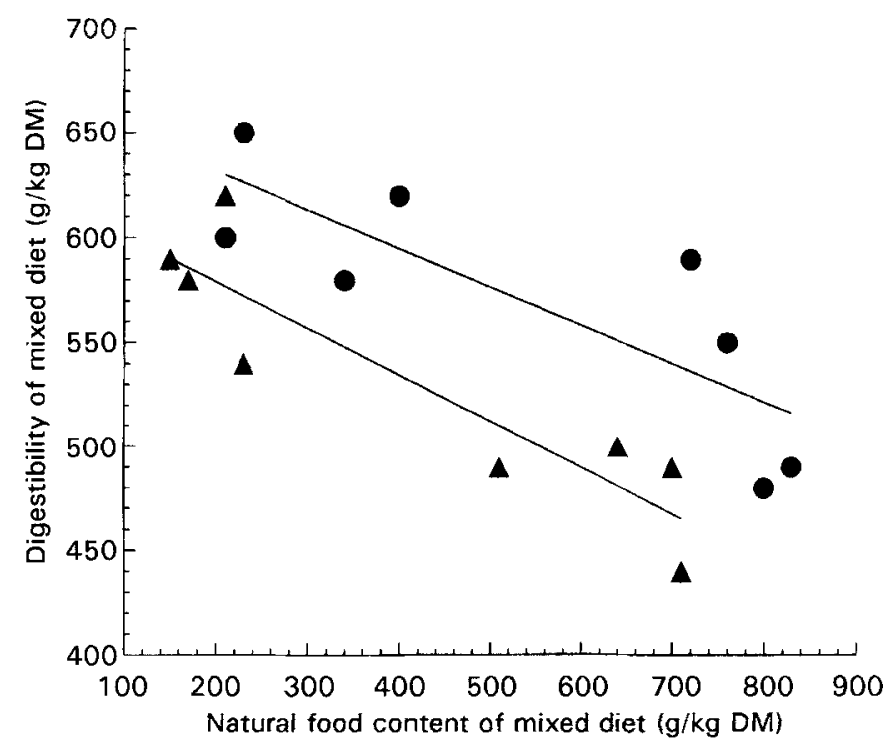

Fig. 1. The digestion by captive red grouse (Lagopus lagopus scoticus) of mixed diets comprising artificial pellets and natural food: heather (Calluna vulgaris; - ) and blaeberry (Vaccinium myrtillus; $\mathbf{\Delta}$ ). The lines are from regression equations. (After Welch et al. 1994.) 


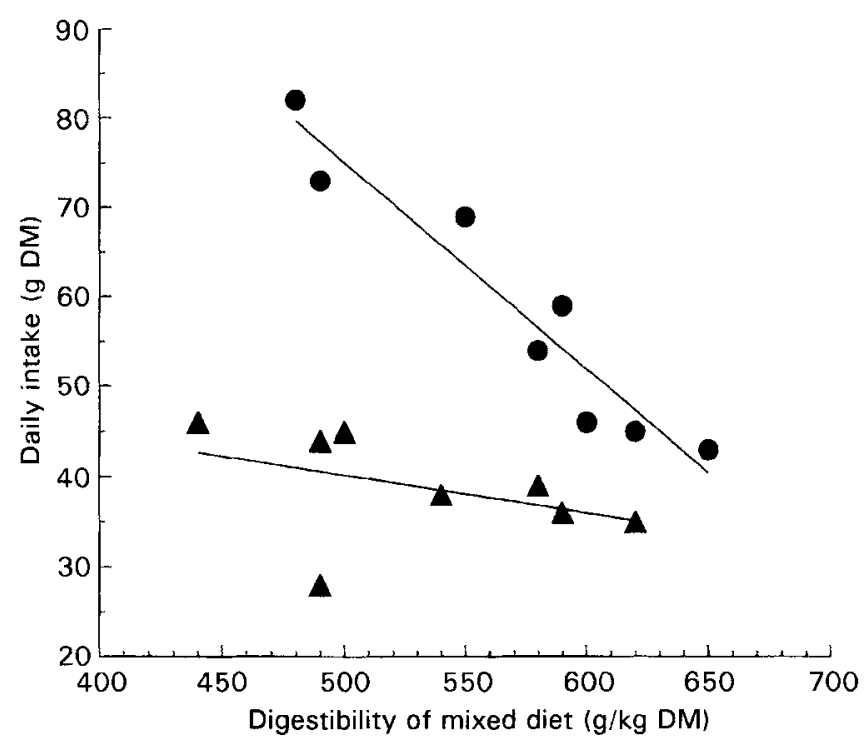

Fig. 2. Daily DM intake by captive red grouse (Lagopus lagopus scoticus) of mixed diets of artificial pellets and fresh foods: heather (Calluna vulgaris; $\mathbf{O}$ ) and blaeberry (Vaccinium myrtillus; $\boldsymbol{\Delta}$ ). The lines are from regression equations. (After Welch et al. 1994.)

They select such food out of proportion to its availability and tend to breed better (more young reared per hen) in years when spring is early, when new growth has been available for longer and when the diet is more digestible (Moss et al. 1990). It is not clear whether the virtue of new growth lies in its high digestible-protein content, in its relatively high digestibility or in both. Furthermore, the causal links between hen nutrition and the number of chicks reared per hen are not immediately obvious. In general, the main determinant of the number of young reared per hen in the wild is chick mortality, because the average number of eggs laid (clutch size) varies little from year to year. Chick mortality is influenced by two broad nutritional factors: indirectly by the diet of the mother (maternal nutrition) and directly by that of the chicks.

The quality of the hens' diet influences chick viability in both red grouse (Jenkins et al. 1965; Moss et al. 1975) and Scottish rock ptarmigan (Moss \& Watson, 1984). This was discovered when samples of eggs were taken from the wild. Chicks were hatched from them and reared in standard conditions in captivity. Almost all chick mortality occurred in the first 2 weeks and the proportion of chicks which died varied markedly between years and study areas (Fig. 3). Breeding success in the wild populations, from which the eggs came, was also measured. Survival in captivity and in the wild both varied, and so it was inferred that both were determined by a common antecedent cause, egg quality.

Chick viability was better on ground overlying relatively-base-rich schist rocks than on nutrient-poor granite (Fig. 3). This was associated with generally higher $\mathrm{N}$ and $\mathrm{P}$ contents in the diet of birds on the richer ground. Calculations for red grouse suggest that protein and $\mathrm{P}$ are likely to be the first two limiting nutrients in their diet, and the same probably applies to Scottish rock ptarmigan (Moss, 1967, 1968).

On the infertile granite, egg quality also tended to be better in years when springs were early and the laying hens had access to new growth of their main food (blaeberry) for longer (Fig. 4). However, on the richer schist the relationship was not clear, possibly because the boost in nutrition provided by spring growth was less important to birds which 


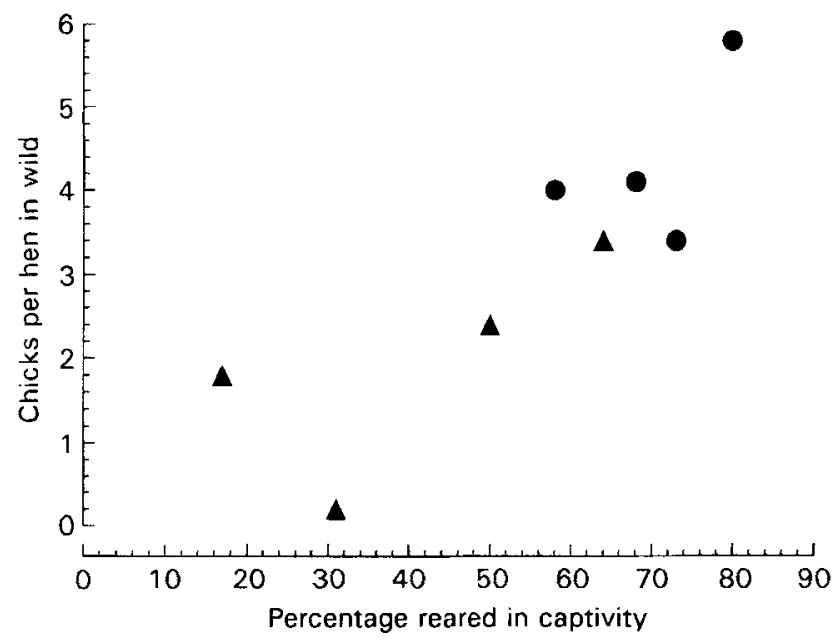

Fig. 3. Rock ptarmigan (Lagopus mutus) breeding performance (brood size) in the wild (1968-71) and proportion reared in captivity from eggs from the same hills in the same years: base-rich soil ( $)$ and infertile soil (A). (After Moss \& Watson, 1984.)

were already on a relatively-rich diet. Of course, Fig. 4 does not necessarily indicate that blaeberry itself was crucial; early growth in blaeberry may simply have indicated early springs. In Sweden, Brittas (1984) found that Vaccinium spp. and new shoots of cotton grass dominated the diet of willow ptarmigan in spring; also, they bred better in earlier springs when the hens had been eating more cotton grass, and the diet was consequently more digestible and richer in $\mathrm{N}$ and $\mathrm{P}$.

As new growth is richer in $\mathrm{N}$ and $\mathrm{P}$ than older material, and $\mathrm{N}$ content is broadly related to digestibility, the logical suggestion from the data described for wild birds is that their breeding success should be related to the $\mathrm{N}$ and/or $\mathrm{P}$ content of their diet, which is affected both by soil richness and by the date of spring growth. However, no such

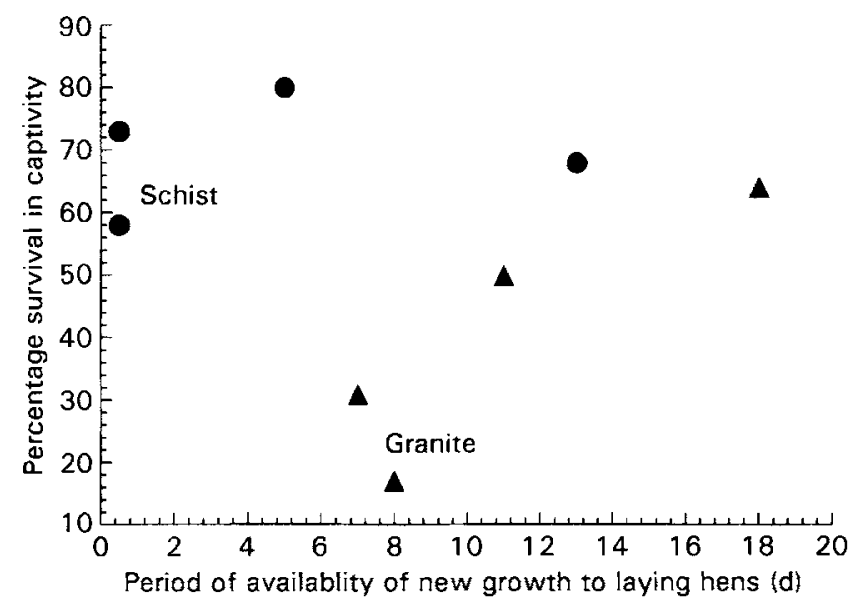

Fig. 4. Percentage survival of rock ptarmigan (Lagopus mutus) chicks hatched in captivity, in relation to the number of days that new blaeberry (Vaccinium myrtillus) growth was available to their mothers in the wild: base-rich soil $(\bullet)$ and infertile soil (A). (Data from Moss \& Watson, 1984.) 


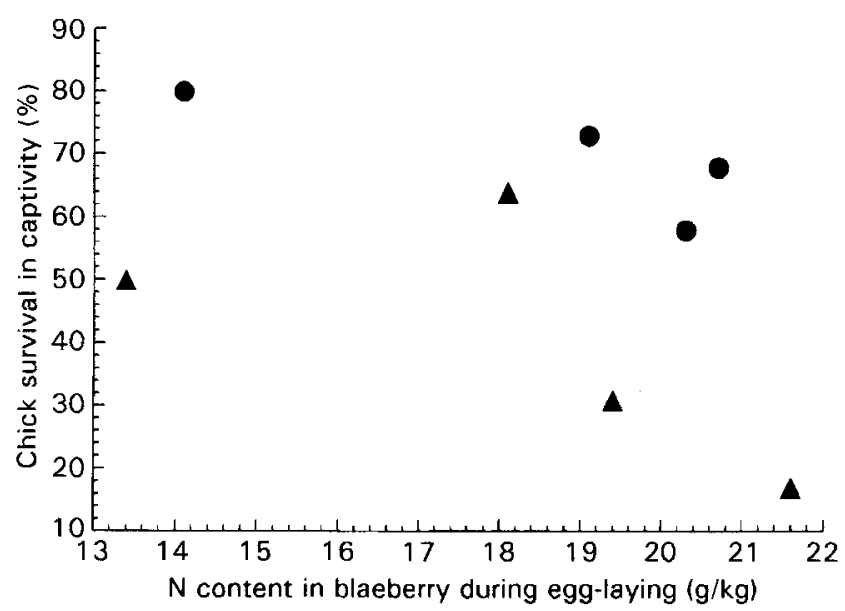

Fig. 5. Percentage survival of rock ptarmigan (Lagopus mutus) chicks in captivity in relation to the nitrogen content of blaeberry (Vaccinium myrtillus) while their wild mothers were laying the eggs: base-rich soil ( $)$ and infertile soil $(\boldsymbol{A})$. (Data from Moss \& Watson, 1984.)

relationships have been observed (Fig. 5). Perhaps the amounts of digestible protein and $\mathbf{P}$ in the diet are more important than their gross amounts. To understand the relationship between new growth and breeding success, we need to know more about the digestibility and utilization of protein and $P$ in fresh, natural diets as well as the roles of possible toxins and digestion inhibitors. As with mammals, crude protein $(\mathrm{N} \times 6.25)$ is not a reliable indicator of nutritional quality (Moss et al. 1990).

Wild birds have to cope with plant defences to get adequate nutrients and energy (Moss, 1991). Perhaps we can avoid such problems in captivity by providing enough of all the known required nutrients? However, survival of chicks from eggs laid by captive hens with seemingly adequate amounts of all known nutrients is no better than that of chicks from wild eggs (Moss et al. 1981). There is more to learn.

\section{CHICK DIET}

In the absence of predation and disease, most chick mortality occurs in the first week or two and is partly attributable to egg quality. Of course, chick diet is also important. By the time the chicks hatch, there is usually much relatively-nutritious plant food available. Nonetheless, in most wild tetraonid populations, the first $2-4$ weeks are crucial because plant food is not enough and the chicks need a supplement of invertebrates.

Ecologists generally pay more attention to chick nutrition than to maternal nutrition and often attribute tetraonid chick mortality to 'starvation', by which they seem to mean a shortage of insect food. A broad rule is that the proportion of insects needed by chicks of different species varies inversely with the chicks' growth rate, such that the fastest-growing species need most insects (Savory, 1989). I have also noticed (Moss, unpublished results) that the fastest-growing species are the most sluggish and easily-exhausted, as if investment in faster growth has a trade-off in less vigour. For example, the large, fastgrowing and sluggish capercaillie (Tetrao urogallus) chicks need a greater volume of insect food for a longer period than slower-growing species such as red grouse (Savory, 1977; Kastdalen \& Wegge, 1991). Capercaillie chicks also rely largely on big and easy-tocatch items such as moth larvae, which presumably provide a high return per unit effort spent foraging. 
Within a species, growth rates of wild chicks are slower than those of well-fed captives (Moss et al. 1993). In the wild, willow ptarmigan grew faster when more insects were available (Erikstad \& Spids $\varnothing, 1982$ ). There is, however, no necessary association between growth rate and survival. Also, despite the obvious importance of invertebrates to tetraonid chicks, there is surprisingly little evidence that the proportion of insects in the diet determines survival.

A useful attribute of the sub-maximal growth rates of wild tetraonids is that some parts of the body seem to have precedence in growth over others. As a result, one can measure an index of condition, related to growth rate, by comparing a chick's weight with the stage of its feather development. Chicks in good condition are heavier at the same stage of feather development than those in poor condition. This has the advantage that chicks need only be caught once. For red grouse (Moss et al. 1993), there was no relationship between annual survival and condition for chicks in average and above-average condition. But the number of chicks reared per hen each year fell increasingly as the index of condition fell further below average (Fig. 6). The relationship between growth rate and survival is likely to show a similar non-linear relationship.

Well-nurtured captives are usually in better condition (as defined previously) than typical wild chicks, and slow growth due to inadequate nutrition should not be a problem. At an anecdotal level, I suspect that unnaturally-fast growth in captives may result in problems of its own. For example, captive grouse and ptarmigan have a dietary requirement for vitamin $C$ (Hanssen et al. 1979) which may be harder to fulfil for fastergrowing chicks.

\section{CAPTIVES AND WILD BIRDS}

It is clear that captive grouse and ptarmigan are quite different from wild ones and that the more generations they are removed from the wild the more different they become (Moss, 1972). Wild tetraonids are on a nutritional knife edge. For example, wild red grouse hens that lay more eggs (ten or more) than average (seven to eight) may in some (but not all) years produce eggs of poor quality so that their chicks suffer heavy early mortality (Moss $e t$

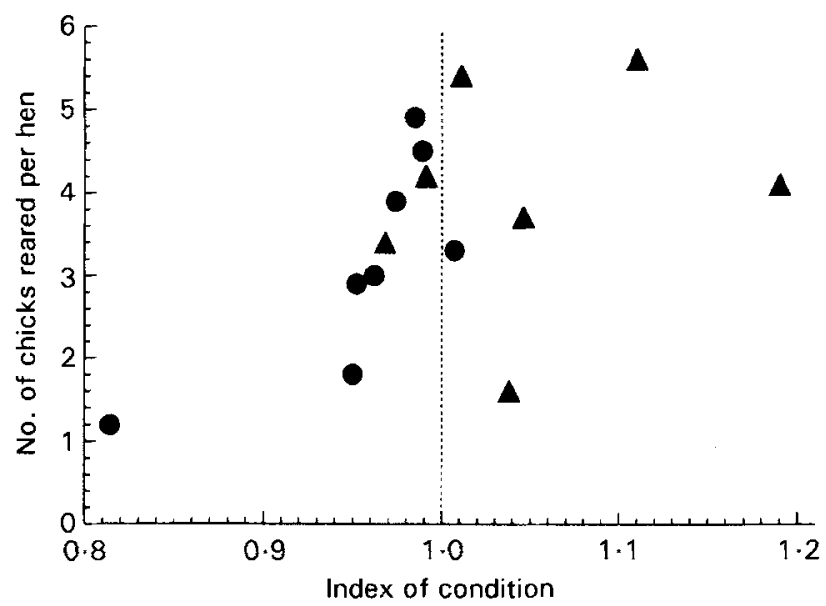

Fig. 6. Average yearly breeding success (young reared per hen) of wild red grouse (Lagopus lagopus scoticus) chicks in relation to an index of condition at two study areas. (), Average condition. (After Moss et al. 1993.) 
al. 1981). But in captivity, on diets rich in nutrients, hen grouse may lay thirty eggs or more with no decline in hatchability or chick survival (Moss, unpublished results).

Many tetraonid adaptations seem designed to get enough protein and other nutrients from their coarse diet. The selection of relatively-digestible and nutrient-rich foods is one adaptation to coarse diets (Moss \& Hanssen, 1980), another is to increase digestive abilities (Moss, 1983). However, the bigger gastrointestinal tracts associated with enhanced digestive abilities have obvious penalties for the birds, which begin to lose them as soon as they are kept in captivity. Large gastrointestinal tracts are probably not the only adaptations lost by captives, which may include detoxication mechanisms necessary to digest new growth.

It follows that there is probably still strong selection for optimum gastrointestinal length, and other physiological characteristics, in the wild. Hence, in removing grouse and ptarmigan from their natural environment and breeding them in captivity, we probably create a domestic creature which becomes increasingly unlike its wild forebears.

\section{REFERENCES}

Brittas, R. (1984). Nutrition and reproduction of the Willow Grouse Lagopus lagopus in Central Sweden. Ornis Scandinavica 19, 49-57.

Chesson, A. (1983). A holistic approach to plant cell wall structure and degradation. Bulletin of the Royal Society of New Zealand 20, 85-90.

Erikstad, K. E. \& Spids $\emptyset$, T. K. (1982). The influence of weather on food intake, insect prey selection and feeding behaviour in Willow Grouse chicks in northern Norway. Ornis Scandinavica 13, 176-182.

Kastdalen, L. \& Wegge, P. (1991). Chick Mortality in Capercaillie Grouse. Ás, Norway: Institutt for Biologi og Naturforvaltning, Norges Landbrukshogskole.

Gasaway, W. C. (1976). Cellulose digestion and metabolism by captive rock ptarmigan. Comparative Biochemistry and Physiology 54A, 467-474.

Hanssen, I., Grav, H. J., Steen, J. B. \& Lysnes, H. (1979). Vitamin C deficiency in growing willow ptarmigan (Lagopus lagopus lagopus). Journal of Nutrition 109, 2260-2276.

Jenkins, D., Watson, A. \& Picozzi, N. (1965). Red grouse chick survival in captivity and in the wild. Transactions of the International Union of Game Biologists 6, 63-70.

Mortensen, A. \& Tindall, A. (1981). On caecal synthesis and absorption of amino acids and their importance for nitrogen recycling in willow ptarmigan (Lagopus lagopus lagopus). Acta Physiologica Scandinavica 113, $465-469$.

Moss, R. (1967). Probable limiting nutrients in the main food of red grouse (Lagopus lagopus scoticus). In Secondary Productivity of Terrestrial Ecosystems, vol. 1, pp. 369-379 [K. Petrusewicz, editor]. Warszawa and Krakow: Institute of Ecology, Polish Academy of Sciences.

Moss, R. (1968). Food selection and nutrition in ptarmigan Lagopus mutus. Symposia of the Zoological Society of London 21, 207-216.

Moss, R. (1972). Effects of captivity on gut lengths in red grouse. Journal of Wildlife Management 36, 99-104.

Moss, R. (1983). Gut size, body weight and digestion of winter foods by grouse and ptarmigan. Condor 85, 185193.

Moss, R. (1989). Gut size and the digestion of fibrous diets by tetraonid birds. Journal of Experimental Zoology Suppl. 3, 61-65.

Moss, R. (1991). Diet selection - an ecological perspective. Proceedings of the Nutrition Society 50, 71-75.

Moss, R. \& Hanssen, I. (1980). Grouse nutrition. Nutrition Abstracts and Reviews 50B, 555-567.

Moss, R. \& Parkinson, J. A. (1972). The digestion of heather (Calluna vulgaris) by red grouse (Lagopus lagopus scoticus). British Journal of Nutrition 27, 285-298.

Moss, R. \& Parkinson, J. A. (1975). The digestion of bulbils (Polygonum viviparum L.) and berries (Vaccinium myrtillus L. and Empetrum sp.) by captive ptarmigan (Lagopus mutus). British Journal of Nutrition 33, 197206.

Moss, R., Trenholm, I. B., Watson, A. \& Parr, R. (1990). Plant growth and nitrogen metabolism of Red Grouse Lagopus lagopus scoticus in spring. Ornis Scandinavica 21, 115-121.

Moss, R. \& Watson, A. (1984). Maternal nutrition, egg quality and breeding success of Scottish Ptarmigan Lagopus mutus. Ibis 126, 212-220.

Moss, R., Watson, A. \& Parr, R. (1975). Maternal nutrition and breeding success in red grouse (Lagopus lagopus scoticus). Journal of Animal Ecology 44, 233-244. 
Moss, R., Watson, A., Parr, R. \& Glennie, W. (1971). Effects of dietary supplements of newly growing heather on the breeding of captive red grouse. British Journal of Nutrition 25, 135-143.

Moss, R., Watson, A., Rothery, P.\& Glennie, W. W. (1981). Clutch size, egg size, hatch weight and laying date in relation to early mortality in red grouse (Lagopus lagopus scoticus). Ibis 123, 450-462.

Moss, R., Watson, A., Trenholm, I. B. \& Marquiss, M. (1993). Growth rate, condition and survival of Red Grouse Lagopus lagopus scoticus chicks. Ornis Scandinavica 24, 303-310.

Savory, C. J. (1977). The food of Red Grouse chicks Lagopus l. scoticus L. Ibis 119, 1-9.

Savory, C. J. (1989). The importance of invertebrate foods to chicks of gallinaceous species. Proceedings of the Nutrition Society 48, 113-133.

Van Soest, P. J. (1982). Nutritional Ecology of the Ruminant. Portland, Oregon: O \& B Books.

Welch, D., Scott, D., Moss, R. \& Bayfield, N. G. (1994). Ecology of Blaeberry and its Management in British Moorlands. Banchory: Institute of Terrestrial Ecology. 